\title{
Sleep deprivation treatment in depression: a review
}

\author{
A. RoY \\ B.A., M.B., B.Chir., M.R.C.P., M.R.C.Psych., D.P.M., M.Phil.
}

S. BHANJI

M.B., B.S., M.R.C.Psych., D.P.M.तె

Maudsley Hospital, Denmark Hill, London SE5 $8 A Z$

\begin{abstract}
Summary
Ten studies, including the authors' own, suggest that sleep deprivation may be a useful treatment in a third to a half of patients with endogenous depression. Caution and a controlled trial are suggested.
\end{abstract}

IN recent years, in a number of centres in different countries, depriving the patient of his night's sleep has been tried as a treatment for depression. Table I shows the findings from ten centres.

Pflug and Tolle (1971) sleep-deprived fifty-seven subjects. The twenty-three healthy subjects and the eleven patients with neurotic depression showed little change in mood, as measured by rating scales. The authors found marked improvement in the twenty- three patients with endogenous depression. Theo greatest changes were in mood, suicidal tendency and 3 retardation. They found improvement was 'noter always maintained' and suggested combination of sleep deprivation with antidepressant drugs.

Lit (1973) sleep-deprived thirty-nine depressed patients once or twice weekly. He found total recovery in thirteen, partial improvement in thirteen, $?$ and no change in eight. Five stopped because of ${ }^{-}$ negative results. He found the best results in seriouse vital depressions.

Voss and Kind (1974) sleep-deprived thirteen depressed outpatients. They found a beneficial effect $\rightarrow$ in eight. Seven of their nine patients with enco-genous depression responded well with 'amelioration'

TABLE

\begin{tabular}{|c|c|c|c|c|c|}
\hline Author & Place & $\begin{array}{l}\text { Number } \\
\text { of } \\
\text { patients }\end{array}$ & $\begin{array}{l}\text { Number } \\
\text { of } \\
\text { nights }\end{array}$ & Results & Comments \\
\hline Pflug \& Tolle & $\begin{array}{l}\text { Tubingen, } \\
\text { Germany }\end{array}$ & 57 & $1-2$ & 23 improved & $\begin{array}{l}\text { Best in endogenous } \\
\text { depression }\end{array}$ \\
\hline Lit (1973) & Holland & 39 & 1-2 per week & $\begin{array}{l}\text { Total recovery in } \\
13\end{array}$ & $\begin{array}{l}\text { Best in serious vital } \\
\text { depression }\end{array}$ \\
\hline Voss \& Kind (1974) & Switzerland & 13 & Weekly & $\begin{array}{l}8 \text { had beneficial } \\
\text { effect }\end{array}$ & $\begin{array}{l}\text { Best in endogenous } \\
\text { depression }\end{array}$ \\
\hline $\begin{array}{l}\text { Van den Burg \& } \\
\text { Van den Hoofdakker } \\
\text { (1974) }\end{array}$ & $\begin{array}{l}\text { Groningen, } \\
\text { Holland }\end{array}$ & 10 & 2 & & No lasting benefit \\
\hline Svendsen (1974) & $\begin{array}{l}\text { Arhus, } \\
\text { Denmark }\end{array}$ & 80 & & $\begin{array}{l}20 \% \text { cured } \\
80 \% \text { benefit }\end{array}$ & $\begin{array}{l}\text { Best in endogenous } \\
\text { depression }\end{array}$ \\
\hline Angst (1974) & $\begin{array}{l}\text { Zurich, } \\
\text { Switzerland }\end{array}$ & 15 & 1 per week & $\begin{array}{l}50 \% \text { had transi- } \\
\text { tional improvement }\end{array}$ & $\begin{array}{l}\text { Is only an adjunct to } \\
\text { tricyclic antidepressants }\end{array}$ \\
\hline Vogel et al. (1973) & $\begin{array}{l}\text { Georgia, } \\
\text { U.S.A. }\end{array}$ & 24 & $\begin{array}{l}5 \text { nights out of } \\
7 \text { for } 3-6 \text { weeks }\end{array}$ & $\begin{array}{l}16 \text { had substantial } \\
\text { improvement }\end{array}$ & $\begin{array}{l}\text { Best results in endogenous } \\
\text { depression }\end{array}$ \\
\hline $\begin{array}{l}\text { Wirz-Justice, } \\
\text { Puhringer \& Hole } \\
\text { (1973) }\end{array}$ & $\begin{array}{c}\text { Basle, } \\
\text { Switzerland }\end{array}$ & 7 & $1-2$ & Some improvement & $\begin{array}{l}\text { Change in platelet } \\
\text { tryptophan values }\end{array}$ \\
\hline Matussek et al. (1974) & $\begin{array}{l}\text { Munich, } \\
\text { Germany }\end{array}$ & 14 & 1 & 7 improved & $\begin{array}{l}\text { Urine norepinephrine } \\
\text { increased }\end{array}$ \\
\hline Bhanji \& Roy (1975) & $\begin{array}{l}\text { Maudsley, } \\
\text { England }\end{array}$ & 28 & $1-14$ & $50 \%$ improved & $\begin{array}{l}\text { Other possible explanation. } \\
\text { Recommend controlled study }\end{array}$ \\
\hline
\end{tabular}


lasting for days or even several weeks'. They noted that treatment could be repeated at weekly intervals and that 'results were less favourable in neurotic or mixed depression'.

Van den Burg and van den Hoofdakker (1975) noted that previous studies had not used 'blind' raters and that many of the patients were on antidepressants. They sleep-deprived ten patients with endogenous depression on two nights only. The patients were drug free for at least 4 days before the study, were given as little attention as possible, and were rated before and after by 'blind' raters. They were unimpressed by the results. There was some improvement on the next day, but after the next night's sleep there was a return to the previous mental state. However, Leigh (1974) has made the pungent comment that two treatments may not be enough to get any worthwhile effect. He notes that the efficacy of electro-convulsive therapy might not have been so noticeable if it had only been given on two occasions.

Svendsen (1974) has sleep-deprived approximately eighty patients with a variety of depressive syndromes. He reported that $20 \%$ were completely cured while the remaining $80 \%$ benefited for periods varying from hours to up to one week. All his patients with endogenous depression were cured. He noted that the procedure was without risk and suggested that it should be the first choice of treatment in both in- and outpatients with endogenous depression. $\mathrm{He}$ found the transient improvement in other depressive syndromes was useful, especially in those with withdrawal, feelings of hopelessness, depressed mood or suicidal impulses.

Angst (1974) has treated fifteen depressed outpatients weekly with sleep deprivation and found that in $40 \%$ a 'transitional improvement' occurred. He considers that sleep deprivation should not be given alone but only with tricyclic antidepressants.

Some workers have tried to find explanations and mechanisms for the improvements claimed after sleep deprivation. Vogel et al. (1973) reported twentyfour drug-free patients with depressive syndromes who slept at night in a sleep laboratory and were awakened whenever they went into REM sleep. Every fourth night they were allowed to sleep uninterrupted. This went on for three to six weeks. Matched control patients were awakened the same number of times, but in non-REM sleep. They found that the patients who did best were those with endogenous depression who were awakened in REM sleep. Vogel et al. (1973) believe that REM pressure is the cause of the improvement. These authors have subsequently doubled the number of patients in their series with similar findings. They have also now followed up fourteen patients who improved and found that two quickly relapsed and were readmitted, but that the remaining twelve, without antidepressants, maintained their improvement for follow-up periods 'ranging from 1 month to 2 years'.

Pflug and Tolle (1971) have written about the disturbance of circadian rhythm in endogenous depression. Van den Burg and Van den Hoofdakker (1974) confirmed this finding that any improvement after sleep deprivation occurred in the last third of the sleepless night and found statistically significant differences in diurnal variation between the day after sleep deprivation and the day after the next sleeping night.

Some biochemical studies have been done. Wirz-Justice, Puhringer and Hole (1973) found, in a group of seven patients with endogenous depression, that the mean platelet monoamine oxidase levels were the same before and after one night of sleep deprivation. The mean free plasma tryptophan was higher at 8.00 a.m. than at 4.00 p.m. before sleep deprivation, but by the second day after sleep deprivation, the trend was for this difference to disappear.

Matussek et al. (1974) found $40 \%$ improvement as recorded by rating scales, in seven of their fourteen patients. The improved group showed a significantly higher urinary norepinephrine/epinephrine quotient before sleep deprivation than the unimproved group and a significant increase in this quotient after sleep deprivation. The increase in urinary norepinephrine in the improved group was also significantly greater than the increase in the unimproved group.

Bhanji and Roy (1975) in their replication study, sleep-deprived thirty-nine out- and in-patients with endogenous depression. Eleven withdrew after one to three nights of sleep deprivation either because they disliked the treatment, failed to come, or because of other social or medical reasons. Twenty-eight patients were sleep-deprived, mostly in small groups, from one to fourteen nights, once or twice a week, for an average four to six occasions. Nine were sleepdeprived only once while five were sleep-deprived from ten to fourteen nights.

The procedure was well tolerated and harmless. Outcome was assessed clinically and by the Wakefield self-assessment depression inventory. The outcome, at completion of treatment, was found to be 'good' (a moderate improvement) or 'excellent' (a marked improvement or complete recovery) in seventeen of the twenty-eight patients, and 'poor' (a deterioration or no change) in eleven. Of the seventeen improved patients, eight relapsed within 3 months but seven were known to have remained improved. No statistically significant relationship was found between outcome and sex, age, length of illness, or past history of affective disorder.

Bhanji and Roy stressed that many of these patients remained on antidepressant drugs, that placebo effects and group processes cannot be 
ignored, and that some depressive illnesses remit spontaneously. They concluded that their replication study showed that sleep deprivation may be a useful treatment in depressive illness, but that a controlled trial was needed.

\section{Conclusion}

Thus, all ten studies claim rapid improvement in mood in depressive syndromes after sleep deprivation. Most agree that this is best seen in endogenous depression and the majority of series report this in a third to a half of patients. Some claim improvement in other symptoms. Some workers state that improvements are only transient while others claim longer-lasting effects. All agree that the procedure is simple and harmless.

Cawley (1967) writing about treatments in schizophrenia, wrote of a once fashionable treatment: 'Subsequent events have shown that the essential elements in insulin coma therapy seem to have been non-specific. ... The increased morale and purpose of medical and nursing staff, the shared experience of an onerous experience, and the fostering of a new kind of group situation, may have been of inestimable benefit to many of the patients ... At the very least, it provided the first modern demonstration in psychiatry of the rewards of therapeutic zeal; and from that time we have never looked back'. These remarks are salutary and relevant to sleep deprivation.

What is now needed is a controlled treatment trial, with an experimental group of drug-free patients, sleep-deprived singly. This is currently being done, using a 'blind rater' with control groups receiving ECT and antidepressant drugs. If the results of this trial are favourable then a follow-up study at 6. months and 1 year is indicated.

\section{References}

Angst, J. (1974) Personal Communication.

BhaNJI, S. \& RoY, A. (1975) The treatment of pyschotic depression by sleep deprivation-a replication study. British Journal of Psychiatry, 127, 222.

CAWLEY, R. (1967) The present status of physical methods of treatment of schizophrenia. In: Recent Developments in Schizophrenia, p. 97. Headley Brothers, Ashford, Kent.

LeIGH, D. (1974) Personal Communication.

LIT, A.C. (1973) Electroschok en Slaaponthouding. Tijdschrift voor Psychiatrie, 2, 56.

Matussek, N., Ackenheil, M., Athen, D., Beckman, H., ஜ Benkert, O., Dittmer, T., Hippius, H., Loosen, P., 3 Ruther, E. \& Scheller, M. Catecholamine metabolism iv under sleep deprivation therapy of improved and not N improved depressed patients. Pharmakopsychiatrie, NeuroPsychopharmakologie, Stuttgart, 7, 108.

Pflug, B. \& Tolle, R. (1971) Disturbance of the 24-hour or rhythm in endogenous depression and the treatment of endogenous depression by sleep deprivation. International Pharmacopsychiatry, Basel, 6, 187.

Svendsen, K. (1974) Personal Communication.

VAN DEN BURG, W. \& VAN DEN HOOFDAKKER, R.H. (1975) Total sleep deprivation on endogenous depression. Archives of General Psychiatry, 32, 1121.

Vogel, G.W., Thompson, F.C., Thurmond, A. \& Rivers, B. (1973) The effect of REM deprivation on depression Psychosomatics, 14, 104.

Voss, A. \& KIND, H. (1974) Outpatient treatment of endo genous depression by sleep deprivation. Praxis, Bern, 6 564.

Wirz-Justice, A., Puhringer, W. \& Hole, G. (1973) Monoamine oxidase and free tryptophan in human plasma. Normal variations and the influence of sleep withdrawal therapy in depression. (Personal Communication.) 